\title{
RAC3 wt Allele
}

National Cancer Institute

\section{Source}

National Cancer Institute. RAC3 wt Allele. NCI Thesaurus. Code C104818.

Human RAC3 wild-type allele is located in the vicinity of $17 \mathrm{q} 25.3$ and is approximately $3 \mathrm{~kb}$ in length. This allele, which encodes Ras-related C3 botulinum toxin substrate 3 protein, plays a role in both GTP hydrolysis and the formation of cell protrusions. 